Artigo Original

\title{
Iconografia das festas populares em Cândido Portinari: sentidos/significados das expressões carnavalescas
}

\author{
Larissa Michelle Lara ${ }^{1}$ \\ Thaís Godoi de Souza ${ }^{2}$ \\ Ana Beatriz Gasquez Porelli ${ }^{2}$ \\ Natália Cristina Ribeiro Cordeiro ${ }^{3}$ \\ ${ }^{1}$ Departamento de Educação Física da UEM, Coordenadora local do Programa de Pós- \\ Graduação Associado em Educação Física UEM-UEL, Líder do Grupo de Pesquisa \\ Corpo, Cultura e Ludicidade da UEM, Maringá, PR, Brasil - CNPq. \\ ${ }^{2}$ Graduada em Educação Física pela UEM. Membro do Grupo de Pesquisa Corpo, \\ Cultura e Ludicidade daUEM, Maringá, PR, Brasil - CNPq. \\ ${ }^{3}$ Curso de Turismo do Centro de Ensino Superior de Maringá, PR, Brasil
}

\begin{abstract}
Resumo: O texto apresenta a pesquisa realizada sobre a iconografia das festas populares em Cândido Portinari, identificando como as imagens criam sentidos para o entendimento da cultura popular e de suas expressões simbólicas. Para tanto, foi necessário apresentar as telas pintadas por Portinari que caracterizam o sub-tema "festas populares", mais especificamente, as telas relacionadas ao "carnaval". Procuramos entender a iconografia de Portinari numa dimensão pedagógica voltada à educação física. Trata-se de um estudo do tipo iconográfico desenvolvido a partir da observação e descrição das imagens em telas, bem como da interpretação acerca do que elas permitem revelar, garantindo a análise objetiva e subjetiva do material de coleta. Tal investigação, enveredando-se pela cultura popular brasileira, reafirma a ideia de que as imagens do corpo festivo em Portinari são densa fonte de pesquisa e recurso pedagógico à área de educação física, merecendo ser potencializadas no processo de formação dos educandos.
\end{abstract}

Palavras-chave: Carnaval. Portinari. Educação Física.

\section{Iconography of popular festivals in Cândido Portinari: Senses/expressions meanings of carnival}

\begin{abstract}
The study presents research on the iconography of popular festivals in Cândido Portinari, identifying how images create meaning for the understanding of popular culture and its symbolic expressions. Thus, it was necessary to present the paintings painted by Portinari that characterize the subtheme festivals, more specifically, the screens related to the carnival. We were understand its iconography the Portinari in a pedagogical dimension focused on physical education. This is a study of the iconographic type evolved from observation and description of the images on screens, as well as the interpretation of what they allow to reveal, ensuring objective analysis and subjective material collection. This research, by venturing to Brazilian popular culture, reaffirms the idea that the body images in festive Portinari are dense source of research and teaching resource for the area of physical education and deserve to be leveraged in the process of training of students.
\end{abstract}

Key Words: Carnival. Portinari. Physical Education.

\section{Introdução}

Mesmo que nossa tradição seja marcada pela tradição verbal como signo universal, é urgente uma leitura da imagem, pois, imagens e palavras são intercambiáveis, mas raramente

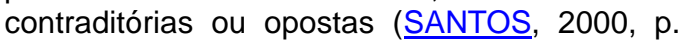
$66)$.

O interesse pela pesquisa iconográfica surge a partir do entendimento de que ela constitui densa possibilidade investigativa em diferentes áreas do conhecimento, embora, ainda, pouco explorada. Pensando essa problemática no campo da educação física e, analisando a trajetória histórica da área, é possível afirmar que o foco na imagem como campo de pesquisa e recurso didático não ultrapassa 30 anos. Isso levando em consideração a utilização da imagem a partir de um recorte sociocultural, e não biológico ou médico, em que seu caráter artístico e, portanto, subjetivo, denotam formas próprias de linguagem e comunicação que se revelam como possibilidades de compreensão do humano.

Cândido Portinari (1903-1962), foi escolhido por suas obras focarem temas recorrentes em nossas investigações, abrangendo, especialmente, as culturas infantis (infância, brincadeiras, brinquedos e jogos) e a cultura brasileira danças, bailes, futebol, personagens populares, retirantes e outros). Sua abordagem 
(festas, trágica, lúdica, cômica, de veemente crítica-social, transporta-nos para cenários diversos, ricos em cores, formas e conteúdos.

Envolvidos pelas obras de Portinari e por seus múltiplos sentidos/significados, antes mesmo de nos aventurarmos pela cronologia do artista, percebemos sua preocupação social, implícita ou explicitamente revelada nas telas, assim como seu potencial criativo, sensível, estéticoexpressivo, que revela muitas facetas humanas, racionalidades que potencializam o próprio existir. Foi este primeiro olhar que nos motivou a tomar algumas obras para investigação e, devido à diversidade de opções, fizemos escolha pelo que move, mais diretamente, nossas necessidades de pesquisa no momento - as temáticas ligadas ao corpo, à cultura e à ludicidade. Nesse sentido, o tema da cultura brasileira e, mais especificamente, do carnaval vem, nesse momento, suprir algumas carências de nossas incursões teóricas, em especial, por revelar a dimensão da imagem.

A opção metodológica pela utilização de imagens como fonte e objeto de nossa pesquisa deu-se pela escolha do tema "Cultura Brasileira", em que Portinari retrata festas populares, religiosidade, jogos infantis, músicos, dança, circo, casamento na roça, espantalho e outros temas diversos. Partindo desse tema, selecionamos o sub-tema "Festas Populares" e, mais especificamente, as telas de "Carnaval", composta por 11 obras do artista. ${ }^{1}$ Quatro das obras que integram a categoria foram pintadas de 1957 a 1961. Das sete restantes, apenas uma integra a década de 1930 e as demais a década de 1940. Daí a análise e a organização das imagens ter se dado de forma cronológica.

Vale observar que a sistematização da produção de Portinari e sua disponibilidade ao público foram idealizadas por seu filho, João Cândido Portinari, já no momento em que o Brasil saía da ditadura militar e que movimentos e projetos eram dedicados a uma revisita ao Brasil, sobretudo por seus artistas (PORTINARI, 2000). O Projeto Portinari (2007) passa, então, a se tornar realidade, com sede na Pontifícia Universidade Católica do Rio de Janeiro, organizando e recuperando as obras de Portinari,

\footnotetext{
1 Essa classificação de Temas e Sub-temas, bem como as obras elencadas em cada uma delas, foi definida a partir do site do Projeto Portinari, disponível em: http://www.projetoportinari.org.br. Acesso em: 07 fev.2007.
}

bem como intensificando sua disseminação nos contextos brasileiro e mundial.

Quanto às descrições e análises das telas pesquisadas, vale observar a dificuldade de se pensar em uma metodologia específica para tal, haja vista que cada pesquisador vai desenvolvendo suas formas próprias, particulares, intimamente ligadas à sua sensibilidade e modos próprios do fazer pesquisa. Contudo, quando nos deparamos com diferentes estudos que utilizam a imagem como foco, percebemos certas aproximações entre eles, que acabam se colocando como modos possíveis do fazer, a exemplo das investigações realizadas por Barroco (2007), as quais tomamos como orientadoras dos caminhos elegidos para essa pesquisa.

Ao falar da imagem, esclarece Santos (2000, p. 63), abre-se uma infinidade de possibilidades, já que certas narrativas falam por imagens e certos objetos são a imagem metafórica de algo que não está posto. Como regra, a imagem seria um "segundo objeto com relação a um outro que ela representa". Assim, duas possibilidades se abrem: "a imagem que pretensamente retrata 0 real, ou fragmentos dele e a imagem que reproduz o invisível, o imaginado [...]." A associação de imagens à pesquisa, na visão da autora, revela que ora a imagem constitui-se como fonte, ora como objeto investigativo, instrumento ou resultado, não apresentando apenas valor estético, mas também epistêmico. Utilizada em pesquisa, deve ser percebida em sua importância, em seus porquês e em sua finalidade.

O texto apresentado, resultante de pesquisa realizada entre os anos de 2007 a 2009, traz reflexões sobre Portinari e as telas pintadas nas décadas de 1930 a 1960. Primeiramente são apresentadas as obras pintadas nas décadas de 1930, 1940, 1950 e 1960, bem como algumas reflexões acerca de sua apreensão como fonte de conhecimento. Após, são desenvolvidas interpretações e análises complementares do material selecionado para estudo. Com isso, esperamos trazer elementos para pensar a arte não apenas distanciada das pessoas, como algo intocável, mas como algo presencial, ligada à realidade dos indivíduos, ressignificada por diferentes traçados, cores, vozes, corpos, que transcendem o espaço da tela para ganhar outros espaços - os do ser humano.

\section{Sobre Portinari e sua arte}

Cândido Portinari, pintor modernista, nasceu em Brodósqui-SP, sendo o segundo de uma família de doze filhos. Sua cronologia é marcada 
por uma vida intensa de dedicação à pintura e, posteriormente, também à poesia, sendo vítima de sua própria arte devido à toxidade das tintas. $\mathrm{Na}$ infância, já pintava estrelas em teto de igreja, ornatos em fachadas de templo cristão e casas, bem como retratos em desenho a lápis. Em 1917, o artista desloca-se para o Rio de Janeiro e, no ano seguinte, integra a Escola Nacional de Belas Artes. Sua primeira tela vendida foi Um baile na roça, quando tinha, aproximadamente, vinte e dois anos de idade. A partir de então, inicia uma série de exposições, ganhando prêmios e viagem ao exterior, o que não o livra das dificuldades financeiras.

$\mathrm{Na}$ Europa, viajou pela Itália, Inglaterra, Espanha e fixou-se em Paris, onde viveu um período de três anos. Durante os anos vividos no exterior, Portinari teve contato com os renascentistas italianos e, principalmente, pôde ter uma visão ampliada do Brasil, em especial, da sua cidade natal. Se no Brasil aprendera técnicas, foi na Europa que o artista descobriu meios de aprimorá-la, valorizando, também, as expressões populares de seu povo, as quais, posteriormente, traduziu em arte.

A temática carnaval foi privilegiada pela arte de Portinari. O artista retrata, em telas, parte do cenário festivo, materializado em formas populares de expressão em que estão presentes música, dança, vestimenta, corpos em movimento, trajes elegantes e característicos de manifestações culturais folclóricas, paisagens, meio urbano, entre outros. Mas, por que o carnaval foi alvo de inspiração artística? O que tem essa manifestação que inspira a representação em telas?

O carnaval, certamente, tem algo de curioso e instigante, sobretudo porque revela a transgressão sem transgredir, permitindo que normas sejam criadas e ressignificadas no tempoespaço da festa para instaurar outro processo normativo. As fantasias carnavalescas, como lembram Tsutsui e Souza (2002), possibilitam, por exemplo, que homens e mulheres troquem seus papeis, provocando desordem e deixando a folia reinar. Há liberdade na relação entre as pessoas, materializada em alegria, prazer, luxúria, uso instrumental do outro, sedução, entre outros. $O$ corpo é sensual, sexual, bêbado, feliz, dançante, observador, contemplativo, namorador, criativo, entre outros. Revela-se nesse tempo-espaço cuja liberalidade é potencializada.
Resistindo às proibições da Igreja que tinha a intenção de "cristianizar" as festas pagãs, o carnaval conquista seu espaço na vida festiva das pessoas. As tentativas de proibi-lo foram inócuas, tanto que a igreja passa a se ajustar a ele, cedendo espaço a essa festividade no calendário litúrgico. A origem dessa festa é tida como europeia, segundo investigações de Tsutsui e Souza (2002), tendo sofrido, no Brasil, adaptações e expansões não atingidas em outros lugares do mundo. Está associada, esclarece Valença (1996), às festas de colheitas abundantes feitas pelos camponeses em agradecimento a seus deuses, sobretudo pela existência de resquícios festivos nos cultos egípcios, na Grécia e na Roma antiga, que serviram de inspiração para a festa popular do Brasil.

Desde o século XVII, os portugueses brincavam nas ruas de Lisboa um carnaval diferente. Correndo desordenadamente de um lado para o outro, atirando ovos crus, líquidos de toda espécie, farinha e substâncias menos limpas nos transeuntes, os lisboetas e habitantes da cidade do Porto participavam de um tipo de carnaval característico da Península lbérica e que daí passou para as Américas portuguesa e espanhola, popularizando-se entre nós (VALENÇA, 1996, p. 10).

As telas de Portinari apresentam tons de brincadeira, espontaneidade, permissividade, que revelam sentidos da festa. Daí ter sido nosso foco nessa investigação. Embora o Brasil não possa ser delineado apenas como país do futebol, do carnaval (samba) e da mulata, porque tais categorias, em si, não são suficientes para descrever um país tão diverso e múltiplo, não há como desconsiderar que essa temática mobiliza muitas pessoas em ações coletivas para que alcancem os objetivos que elegem para si e para o grupo. Daí nosso interesse pelas imagens que falam muito de um carnaval brasileiro das décadas de 1930 a 1960, que mobiliza as pessoas num determinado contexto social, diferente e, ao mesmo tempo, semelhante a muitas expressões carnavalescas da contemporaneidade.

As 11 telas selecionadas para o estudo abrangem as décadas de 1930 a 1960 e são apresentadas em ordem cronológica. Compõem o sub-tema "Festas Populares", mais especificamente, o "Carnaval". Nesse período, não observamos o mesmo Portinari. Podemos dizer que tanto os interesses quanto sua representação por meio das telas são 
diferenciados, materializados em fases do artista, permeados pelo contato com a cultura brasileira e estrangeira, experiências que vai adquirindo e aprimorando ao longo de sua vida.

As telas eleitas para análise têm características diferentes e aproximadas. Revelam a alegria da festa sem, no entanto, tornar evasiva sua expressão eufórica. O corpo, em movimento, é que realça a ebulição festiva. Corpos brancos e refinados, em tons brancos, vermelhos e azuis, são evidenciados em telas como Maria Rosa no Carro, Desfile de Carnaval e Reisado, contrastando com os corpos negros e opulentes das telas Bloco Carnavalesco, Morro, Carnaval e Frevo, em preto e branco, ocre ou vasto colorido. Esses corpos, por vezes, mesclam-se nas telas, embora sejam mais ou menos privilegiados em cada uma delas. A ausência do corpo (materializado) revela-se em Máscara, embora sua presença se dê no movimento que a pintura traz, nas cores elegidas e nos objetos que a compõem. As formas trazem sentimento e, com ele, a pessoa, o ser humano. Não há como ignorar essa relação.

Há desenhos que se repetem, a exemplo de Maria Rosa, do cavalo-marinho e dos músicos, personagens que compõem mais de uma tela. $A$ década de 1930, com Bloco Carnavalesco, marca a expressão popular pelo aglomerado de pessoas, pela euforia de comungar juntos de uma mesma festa. A década de 1940 retrata um carnaval que mescla as culturas erudita e popular, cujo foco está nos músicos, nos observadores da festa ou foliões de camarote (telas de 1941). Há um ingresso direto na cultura popular por meio das telas de 1942. As décadas de 1950 e 1960 são marcadas pela expressão cubista de Portinari, transitando entre o preto-branco e o colorido, momento em que são acentuados traços da cultura popular brasileira, como o cangaceiro, o cavalo-marinho, o capoeirista e a portaestandarte. A expressão popular atinge, nessas últimas telas, formas inigualáveis: corpos que se misturam à estrutura cubista; cores que se tocam, fundem-se e transcendem; personagens que dão sentido e vida às telas.

\section{O carnaval da década de 1930 em Portinari}

Buscando argumentos para o entendimento das obras de Portinari, principalmente para a década de 1930, lembramos Fabris (1990, p. 73) ao afirmar que os anos de 1931 a 1939 representam a expressão própria do artista, ou seja, o momento em que ele, após retorno da Europa, define de modo peculiar traços de sua arte. É quando começa a retratar o povo brasileiro em suas telas e inicia contatos e encontros com os intelectuais da época. Em pouco tempo, em uma reunião, ele é

[...] (escolhido como figura-símbolo do Modernismo por sua anterior experiência acadêmica e por sua descoberta dos princípios da nova arte num aprendizado longo e pessoal) [...]. (FABRIS, 1990, p. 73)

Esse período, lembra a autora, representa a fase do "choque", isto é, as comparações entre a arte acadêmica que aprendera na sua nação e a européia que se mostrava moderna e adiantada em relação à brasileira. Foi com o choque que 0 pintor aprendeu a ver a arte e a descobrir o Brasil. Isso porque

[...] o choque é tão mais valioso, pois o leva a questionar o ensino até então recebido, a repensar a arte em sua expressão específica, a partir em busca de suas raízes. (FABRIS, 1990, p. 43).

A primeira fase de Portinari é dominada por tons marrons e suas preocupações são de caráter construtivo, ou seja, composição da tela, dinâmica espacial, pesquisa de formas e cores que permitam exprimir a visão da própria terra e da própria gente. Ainda, em relação ao mesmo período, a autora revela que Portinari já possui o domínio técnico do desenho e "[...] um cromatismo que vai dos tons pardacentos às nuanças mais delicadas, que atingem, às vezes, tons pastéis" (FABRIS, 1990, p. 45).

A década de 1930 apresenta apenas uma única tela do sub-tema Carnaval, chamada Bloco Carnavalesco ${ }^{2}$, obra em preto e branco, do ano de 1933, assinada na margem inferior à esquerda por Portinari, sem ano, na cidade do Rio de Janeiro. Hoje, a obra encontra-se em uma coleção particular em São Paulo-SP.

Em relação ao conteúdo da obra, a pintura apresenta diversas pessoas, todas próximas umas às outras, com expressões alegres, entusiasmadas, bem humoradas, em clima de festa. Elas demonstram dançar ao som de uma música ritmada em um espaço aparentemente urbano devido à iluminação realizada por uma lâmpada de poste bem ao fundo da tela. As expressões faciais apresentam bocas entreabertas, rostos serenos, desconfiados, e até

\footnotetext{
${ }^{2}$ A obra Bloco Carnavalesco, de 1933, é um desenho feito a crayon/papel e pode ser encontrada em: http://www.portinari.org.br.
} 
excitados. O grupo que se encontra exibido é misto (feminino e masculino). Observa-se, também, uma bandinha passando entre os sujeitos dançantes. Os corpos são robustos e fortes e os lábios volumosos, característica do negro, figura dominante na tela. Os corpos, mesmo na imagem estática, são inteiramente dançantes. Demonstram isso, sobretudo, nos membros distantes do centro do corpo, como braços para os lados e para o alto, assim como pernas afastadas. Representam a cultura negra nos traços e, parecem, também, retratá-la na música, o que não é de se estranhar, haja vista a possível origem negra do samba, a exemplo dos estudos de Cascudo (2000). Chama atenção um personagem que usa vestido, mas que, contrariamente às outras personagens femininas, não calça sapatos, sendo representado com os pés no chão e aparente cavanhaque. Instiga-nos a construção desse personagem, uma vez que ele pode representar a própria liberdade de expressão que o carnaval possibilita, já na década de 1930, ou ainda, a própria liberdade em relação à sexualidade.

Observando os corpos nesta tela, vemos que, sem exceção, todos exibem determinadas partes do corpo de modo ressaltado, como pés e mãos. Fabris (1990) confirma este dado ao mencionar que as obras de Portinari apresentam composições dominadas por figuras exageradas, as conhecidas deformações expressivas típicas do autor, exibindo pés e mãos grandes que simbolizam a força de trabalho, dando ênfase à figura humana.

Essa tela apresenta traçados diferentes de outras obras pintadas por Portinari em décadas posteriores, quando elementos de uma arte cubista passam a ser incorporados à sua trajetória. Entretanto, os corpos fortes, vigorosos, robustos, continuam a ser delineados a partir do negro e de sua alegria festiva.

Jogos didáticos que explorem as imagens, em seus diferentes vieses, reforçam meios educativos possíveis no cotidiano da docência. Trabalhar, por exemplo, com a imagem Bloco Carnavalesco, perguntando como os alunos veem aquelas pessoas em movimento, pode denotar como eles se relacionam com os corpos negros, opulentos e festivos. Ainda, podem revelar se eles apresentam dificuldades de trabalhar conhecimentos ligados à determinada etnia e se visualizam como importante a Lei n. 11.645/2008, que trata da obrigatoriedade do conhecimento da cultura afro-brasileira e indígena no contexto escolar. Tal ação, não só em relação a essa obra, mas decorrente do trato com tantas outras repletas de elementos significativos para a formação, constituem possibilidades de ampliar a experiência estética dos educandos, aguçando seu campo perceptivo.

\section{De 1940 a 1960: os corpos carnavalescos}

$\mathrm{Na}$ década de 1940, Portinari pintou painéis para a Rádio Tupi do Rio de Janeiro e São Paulo, encomenda feita por Assis Chateaubriand (jornalista, escritor, professor, mecenas e político brasileiro), tendo alguns deles retratados músicos, sambistas e trabalhadores. A série exibiu o modo de ser do povo carioca, no seu jeito descontraído e popular. Nas telas, "[...] braços e pernas vigorosos opõem-se a um rosto apenas esboçado de nariz triangular e grandes olhos arregalados" (FABRIS, 1990, p. 57). Essa década é marcada por um carnaval que traz classes sociais distintas, geralmente configuradas na figura do branco (folião bem caracterizado e/ou músico, por vezes, em carros alegóricos; ou apenas observador) e do negro (corpos opulentes, dançantes, entregues à festa, numa expressão nem sempre eufórica).

A obra Desfile de Carnaval $^{3}$ emprega cores amarela, azul e vermelha, com 0 preto de contraponto. Esta também é uma ilustração presente no livro Maria Rosa, de Kelsey (1983). A cena que predomina é um espaço urbano, como a visão panorâmica da avenida de uma grande cidade, cercada de prédios e iluminada por poucos focos de luz que vazam por entre os prédios e seguem em direção a uma espécie de arquibancada. O que embeleza e dá vida à avenida cinzenta é o colorido desfile de carnaval. Observam-se carros que transitam em uma avenida e num único sentido transportam foliões, em meio a outros que brincam o carnaval. Há pessoas que assistem ao espetáculo em camarote e outras paradas ou em circulação do outro lado da avenida, já retratando o carnaval em sua condição não meramente popular, uma vez que essa distinção demanda diferentes condições para participar da festa: uns pagam seu próprio reduto, com condições de assistir a toda festa sem ser incomodado pelo corpo a corpo dos populares; outros pagam ou não para assistir ao

\footnotetext{
${ }^{3}$ A obra Desfile de Carnaval, de 1941, é desenho a guache e nanquim pincel/papel e pode ser encontrada em: http://www.portinari.org.br
} 
desfile, mas em meio ao fervor dos que assistem ao espetáculo e vibram com ele.

Pequenos traçados são utilizados por Portinari para sugerir a ideia de movimento, principalmente dos braços encontrados abertos e erguidos, e nos corpos das pessoas que se debruçam nos camarotes para lançar serpentinas sobre os que desfilam. Em cada gesto representado há euforia e contentamento, por mais que não seja nitidamente visível a expressão das pessoas.

Não fica identificado ao certo quem são os homens e quem são as mulheres. Apenas no canto direito percebemos um casal de pele clara, em que o homem veste um terno e a mulher um vestido vermelho. Próximo a este casal, um pouco mais ao centro da tela, identifica-se uma pessoa, também branca, trajando uma fantasia vermelha, com chapéu pontudo, que faz alusão ao palhaço. Já no canto esquerdo da figura, em meio ao desfile, podem ser observados outros dois personagens: um homem negro fantasiado de índio e uma mulher negra vestindo uma saia longa e rodada, com camiseta branca e um acessório amarelo na cabeça. Os demais traçados expressam pessoas, mas não são tão facilmente identificados.

Maria Rosa no Carro ${ }^{4}$ é uma tela de 1941. Portinari pintou essa tela quando estava em Washington/ EUA. O desenho corresponde à llustração no 16 do livro Maria Rosa, de Kelsey (1983). Há pouco colorido, destacando-se o vermelho, o azul e o preto para apresentar um carnaval que se passa no espaço urbano. $\mathrm{Na}$ ilustração, são visíveis um poste, e um carro com duas mulheres/meninas e um homem. Sobre eles são lançados confetes e serpentinas.

Uma das personagens femininas traja vestido vermelho, com muitos babados e faixa preta na cintura. Tem grandes olhos, boca delicadamente pintada de vermelho, rosto arredondado e cabelos encaracolados soltos. A outra tem cabelos também encaracolados, presos por um grande laço, e usa vestido azul. Apresenta rosto fino, olhos pequenos, nariz arrebitado e boca contornada. O homem que acompanha as duas tem um rosto sério, sobrancelhas grossas, testa franzida, boca delineada com apenas um leve traçado e nariz comprido. Veste terno, sapatos e gravata borboleta preta e um pequeno chapéu

\footnotetext{
${ }^{4}$ A obra Maria Rosa no carro, de 1941, é desenho a guache e nanquim bico-de-pena e caneta-tinteiro/cartão, disponível em http://www.portinari.org.br.
}

vermelho que lembra o acessório usado pelos padres e bispos.

Eles participam do carnaval, seja desfilando (parte da festa) ou se dirigindo até ela por uma avenida. Não há expressão de euforia ou algo parecido por parte deles, nem, ao menos, alguma movimentação. A ideia de uma cena não estática é dada pelo carro e pelas serpentinas e confetes que são lançados sobre eles. Todavia, parece haver mais alvoroço e animação na platéia, que não pode ser vista e que lança os confetes e as serpentinas, do que nas pessoas que estão no carro desfilando.

Reisado ${ }^{5}$ encontra-se hoje em uma coleção particular no município de Fortaleza-CE, pintada no ano de 1941, em Washington-EUA. Essa tela é a ilustração $n^{\circ} 20$ do livro Maria Rosa, de Vera Kelsey (1983). A manifestação apresentada em tela é o Reisado, também conhecido como Folia de Reis, realizado de formas diferenciadas em todo o Brasil. O folguedo está ligado ao período natalino, comumente no mês de dezembro para celebrar o nascimento do menino Jesus, estendendo-se até 06 de janeiro, dia de santo reis. Entretanto, é comum vermos esta manifestação popular integrando a festa carnavalesca, como retratado por Portinari, uma vez que muitas manifestações populares religiosas passam a assumir também conotações profanas próprias de outras festas.

Nesta tela, observamos personagens próprios do reisado, como o rei ao fundo da tela, juntamente com o cavalo-marinho - personagem ao centro montado em seu cavalo. Maria Rosa, que aparece na tela Maria rosa no carro (1941), encontra-se posicionada ao lado do rei, assistindo a festa e reforçando a condição de integrante de classe social elitizada, que não se mescla ao popular, mas o toma como espetáculo. Observam-se também outros personagens que seguem no cortejo, gerando interrogações. Estariam representados em forma de caricatura, com nariz de tamanho exagerado ou triangular, com traços acentuados e deformados, ou se tratam de máscaras postas ou pintadas pelos participantes da festa? O curioso é que todos usam chapéus. Vermelho e azul são as cores predominantes na tela, em roupas e no próprio corpo, o que em muito se assemelha à pintura de Maria Rosa no carro (1941) e à tela Desfile de 
Carnaval (1941), anteriormente retratadas. Serpentinas e confetes vêm do alto e compõem a tela junto com os personagens.

A obra Máscara ${ }^{6}$ aparece na ilustração $n^{\circ} 2$ da obra de Kelsey (1983) e apresenta objetos utilizados no carnaval, passíveis de interpretações diferenciadas. Um deles pode ser um prato, um pandeiro, um porta-tintas; outro, pode ser um vaso, um tambor, um barril, entre outras possibilidades. O que parece melhor definido é a máscara, com expressão curiosa (nem triste, nem sorridente; talvez, meio sarcástica), e a serpentina, que se mistura aos objetos. As cores predominantes e complementares são amarelo e azul, que organizam o espaço da tela formando a linha do horizonte. Dão sentido especial à figura. Parecem representar terra e céu; materialidade e infinito.

A máscara é ícone do carnaval, da criação de personagens, da rebeldia necessária, do instaurar de outra ordem, possível pela implementação de um tempo-espaço próprio. Na Idade Média, por exemplo, como tentativa de pôr fim às festividades, a igreja impôs o uso de máscaras e fantasias nas festas ditas pagãs. Vale lembrar que esse período foi caracterizado pelo surgimento do cristianismo e quem ditava as regras e a censura era a igreja. A imposição tornou-se hábito nas festas de carnaval. Ainda, no final desse período e início do renascimento, as máscaras eram usadas nos famosos "bailes de máscara", quando, por meio desse acessório, mesclavam-se diferentes classes sociais à medida que não se reconhecia, teoricamente, quem era plebeu e quem era nobreza (VALENCA, 1996).

A obra Morro ${ }^{7}$, pintada em preto e branco, encontra-se inserida na Série "Os Músicos", de Portinari, que tem como tema a música brasileira. O carnaval por ela representado se passa na favela, que está sobre um morro, vizinho de vários outros. No cenário ao fundo percebem-se cercas de madeira demarcando alguns espaços, com sombreamento um tanto desbotado. Observa-se, também, uma cidade cercada pelos morros, com prédios altos. Provavelmente seja a cidade do Rio de Janeiro- RJ. A cena principal ocorre em

\footnotetext{
${ }^{5}$ A obra Reisado, de 1941, é um desenho a guache, lápis de cor e nanquim bico-de-pena/papel, disponível em: http://www.portinari.org.br.

${ }^{6}$ Máscara é obra de 1943, pintura a óleo/cartão, disponível em: http://www.portinari.org.br.
}

primeiro plano, no morro, onde se dá o carnaval carioca.

$\mathrm{Na}$ tela em questão, a festa de carnaval acontece distante do centro da cidade, uma vez que ela se dá nos morros, caracterizados por cercas de madeira, casas humildes, formato quadrangular e terra batida. Os traçados sugerem pessoas descendo o morro sobre um chão esburacado/sujo e embaixo de sol, já que há sombra nelas e não há presença de postes de luz. A banda, composta por um clarinetista e tocador de cavaquinho, vai à frente como se conduzisse as pessoas.

A face de cada um dos personagens é ressaltada por traços cubistas que aparecem no nariz triangular e no formato quadrado dos dedos das mãos. O cavalo, que vem logo ao centro da tela, também traz este traçado materializado em sua cabeça, sendo a representação em evidência em várias obras de Portinari. Trata-se do cavalomarinho, folguedo que integra a cultura popular pernambucana, composto de diálogos, danças e brincadeiras, cujos personagens são humanos e animais. Na tela de Portinari, apenas aparece um deles - o Capitão - cujo nome é Marinho, montado em seu cavalo, uma vez que sua imagem já faz alusão ao folguedo.

Após a figura do cavalo-marinho aparece um homem trajando camiseta listrada e calça clara, que dança com os braços para o alto. Em seguida, observa-se uma mulher dançando com vestido exibindo as pernas e, logo, um aglomerado de pessoas que parecem dançar, com braços projetados para 0 alto. Portinari expressa o movimento dos corpos das pessoas e sugere essa dinâmica em sua obra. De modo geral, com exceção dos músicos, as pessoas movimentam seus corpos, com acenos ou braços para o alto, no sentido de euforia/festividade.

Enquanto na festa carnavalesca retratada em Maria Rosa no Carro, Desfile de Carnaval e Reisado, todas de 1941, ocorria o distanciamento físico, com separação nítida entre brincantes e prestigiadores, em Morro, as pessoas se agregam na festa, mesclando-se aos brincantes, num cenário rústico, em área pobre da cidade, em meio a condições diversas. Mesmo assim, Morro não deixa de demonstrar suas contradições sociais, quando a brincadeira carnavalesca do

\footnotetext{
7 A obra Morro, de 1941, é painel a têmpera, disponível em: http:// www.portinari.org.br.
} 
morro mescla-se ao cenário da cidade, reforçando as diferenças sociais.

Analisamos, também, a obra Carnaval $^{8}$, desenho a grafite e lápis de cor, feito no papel, estudo para o painel Morro, da Série Os Músicos. Se visto brevemente, pode se dizer que são meros rabiscos; apenas um rascunho para um grande painel. Entretanto, quando analisado, percebem-se particularidades de detalhes, não executados no painel Morro, por Portinari.

O desenho tem como tema social a favela. $O$ espaço apresentado é dividido por uma ruela com escadarias, que sugere a altitude do morro em que a favela está. Dos dois lados da rua existem casas pequenas e quadrangulares, praticamente iguais. Os músicos descem o morro pelas escadarias e as outras pessoas seguem-nos.

Os músicos são dois clarinetistas. Possuem o nariz triangular e os olhos arregalados. O que está localizado no lado direito da tela tem bigode, usa chapéu pequeno e camiseta por baixo de um paletó largo e longo. O clarinetista, à esquerda, veste camiseta listrada. Em seguida, há uma mulher trajando saia longa, rodada e com babados, uma regata desfiada na barra e um acessório na cabeça. Logo atrás tem um homem com as pernas cruzadas, vestindo calça e regata listrada, interagindo com 0 personagem do cavalo-marinho. A seguir, outras mulheres descem as escadarias vestidas de saias longas e rodadas, com blusas recortadas na barra. Em nenhum deles pode-se dizer que há expressão definida de um sentimento ou estado de espírito, algo comum nas telas investigadas de Portinari. Mesmo assim, há movimento expresso no desenho, observado pelos braços levantados e pernas cruzadas. São corpos que dançam no espaço.

\section{Telas das décadas de 1950 e 1960}

Datada de 1957, Carnaval $^{9}$ é desenvolvida em aquarela e grafite/papel, e integra coleção particular, localizada na cidade de São Paulo-SP. Tem predominância da coloração marrom, e das tonalidades ocre e bege. Carnaval é imagem que retrata a festa carnavalesca em sua ampla gestualidade, representativa das tradições culturais brasileiras. O cangaceiro (lampião), personagem histórico típico da cultura popular

\footnotetext{
8 A obra Carnaval, de 1942, é desenho a grafite e lápis de cor/ papel, disponível em: http:// www.portinari.org.br.

9 A obra Carnaval, de 1957, é desenho em aquarela e grafite/papel, disponível em: http:// www.portinari.org.br.
}

brasileira (herói nordestino) aparece ao centro da tela, em destaque. Algumas imagens se sobrepõem e dão a ideia de movimento, de brincadeira, de ludicidade própria da festa. As várias partes formam o todo. Os personagens movimentam-se com danças típicas, como frevo, representado por três mulatos dançando com uma sombrinha de cor preta. O corpo aparece retratado, ainda, de ponta cabeça, amparado num braço só, no rolê da capoeira, dentro do cavalomarinho, tocando instrumentos musicais e também apreciando a festa, como expectador. Um homem, no canto esquerdo acima, toca uma flauta, usa chapéu, e paletó; outro, do lado direito, conduz um chocalho, tendo a platéia ao fundo. Um menino se movimenta no chão executando um movimento gímnico de flexibilidade. Os traços do rosto são praticamente invisíveis, tornando múltiplas suas formas de leitura. A roupa, de cor crua, contrasta com a pele morena.

As cores terrosas com pinceladas em laranja e o chão ocre contrastando com a cor clara das vestimentas são utilizadas de forma harmoniosa. Personagens, gestualidade e música formam um todo harmônico que se traduz na assimetria das formas. Pés, mãos, braços e pernas são ressaltados, como em muitas telas do artista, pois estão vinculados ao homem popular, trabalhador, explorado por sua condição social, mulato, cuja linguagem gestual é enriquecida pelas experiências acumuladas a partir de uma vida menos regrada a normas sociais. Tais traços são comentados por Luz (1985) ao discutir os Retirantes, sobretudo ao afirmar que mãos e pés ciclópicos, desmesurados, são intensamente retratados nas obras de Portinari.

Também chamada Carnaval ${ }^{10}$, a obra de 1960 compõe coleção particular, localizada em Washington, USA. Aparecem tons frios de azuis e verdes que se mesclam, acrescido de vermelho, amarelo, laranja e, também, branco, preto e terra, dando vida às formas geométricas. Retratada em cores fortes, traz a marca do expressionismo de Portinari. A tela retrata a festa de carnaval do Rio de Janeiro. Logo à frente vê-se um homem no cavalo-marinho que aparece com os pés claramente desnudos e ressaltados aos nossos olhos. Acompanhando este brincante no cortejo estão a porta-bandeira e os demais brincantes. Existe também uma bandinha, em que homens

\footnotetext{
${ }^{10}$ Carnaval, de 1960, é uma pintura a óleo/cartão, disponível em: http:// www.portinari.org.br.
} 
portam objetos instrumentais como: flauta, violão, cuíca e clarinete. Os personagens que desfilam no carnaval são negros, inclusive a platéia que se encontra ao fundo do lado direito da tela, com exceção para os tocadores de flauta e clarinete.

Aqui, os rostos surgem melhor definidos, mas em formas singelas, sem expressões claramente esboçadas, deixando aberto ao leitor suas interpretações. Não denotam o êxtase da festa, mas, contrariamente, revelam incógnitas. A pele negra mescla-se à branca. $O$ tema do reisado, pintado por Portinari em outras telas, aparece representado nessa obra, em seu centro. Três músicos estão calçados e bem vestidos, usando calça, paletó, camiseta e sapato social. O tocador de cuíca exibe-se com indumentária simples, situado ao lado do violonista. Há outro homem agachado ao lado do violonista, que assiste 0 desfile.

O grupo segue em movimento, numa espécie de cortejo, de passagem, enquanto a plateia, novamente, parece atenta ao foco da festa, nos vários rostos que expressam a diversidade de nossa formação étnica. Música, dança, expressão da religiosidade na festa profana, configuração de personagens, relação artista-público, são aspectos facilmente observados nessa tela.

A penúltima imagem pesquisada, Frevo ${ }^{11}$, data de 1961, criada pelo artista para decorar um dos salões do late Clube de Belo Horizonte-MG, projeto do arquiteto Oscar Niemeyer ${ }^{12}$. Em toda a tela são utilizadas muitas formas geométricas, linhas retas, diagonais e paralelas, que dificultam uma leitura objetiva. A imagem Frevo parece ser resultado da sobreposição das telas anteriores, mescla de objetividade e subjetividade, de traços nítidos e foscos. Traz o colorido da segunda imagem do carnaval em tons que se tornam claros na parte inferior da tela, mesclados ao tom de terra da primeira imagem, bem como alguns de seus atores sociais.

Nessa tela aparece uma pessoa segurando estandarte, com traços femininos acentuados. Um dançarino de frevo porta sombrinha. Seus braços e mãos são ressaltados, dando ideia de movimento a acompanhar a música e o desfile. Outros dançarinos de frevo se tornam quase que

\footnotetext{
${ }^{11}$ Frevo é obra de 1961, painel a óleo/madeira, disponível em http:// www.portinari.org.br.

12 Informações sobre as telas retiradas do Projeto Portinari, cujos direitos autorais pertencem a João Cândido Portinari. Disponível em www.portinari.org.br. Acesso em: 07 fev. 2007.

imperceptíveis em meio à fusão com as figuras geométricas, acentuando a subjetividade da tela.

Em relação às características da imagem, percebemos visivelmente a dança popular de Recife - o frevo - típica da região de Pernambuco, que teve sua origem a partir da música no repertório das bandas militares, na segunda metade do século XIX (CÔRTES, 2000; SILVA, 2000). O vocábulo frevo é derivado de fervorescente e ferver, palavras pronunciadas pelos populares por frevorescente e frever. Para Cascudo (2003), o significado de frevo é confusão, rebuliço, agitação popular. Portanto, ele nasceu do povo, isto é, dos populares, da classe excluída socialmente. A dança (frevo), a partir de 1930, dividiu-se em frevo de rua (caracterizado por acompanhamento de instrumentos de sopro e sem letra); frevo de bloco (acompanhado por orquestra de instrumentos de pau e corda) e frevo-canção (com melodia). Algumas características do frevo são percebidas na imagem, trazendo peculiaridades do frevo de rua, em que se observam instrumentos de sopro.

Vê-se retratados na pintura o cangaceiro, quase ao centro da imagem (à direita), e disposto à frente da platéia, a qual assiste ao espetáculo com expressão facial rude. Ao seu lado está o cavalo marinho. Na plateia, há músicos tocando violão, flauta e clarinete. Muitas pessoas seguram e usam máscaras e fantasias. Mulheres que estão de vestido calçam sapatos de salto. Um homem, no primeiro plano, toca violão sentado em um tipo de banquinho artesanal, no formato de uma caixa, vestindo calça, camiseta, paletó e sapatos. O restante esconde-se, mescla-se e eleva nosso campo imaginativo. São várias faces, reais, criadas, representações que integram o cenário festivo. Pés desnudos misturam-se aos pés contidos em sapatos. O corpo aparece em meio às diferenças, harmonizando-se na contradição, movimentando-se em suas necessidades expressivas - dançantes, gímnicas, capoeirísticas - seja em sua gestualidade contida ou expansiva.

A última imagem investigada recebe o mesmo nome da anterior (Frevo ${ }^{13}$ ) e também data do mesmo ano. Informações do Projeto Portinari (2007) afirmam que essa obra, nas cores preto e branco, é uma maquete para o painel Frevo colorido, sendo de coleção desconhecida. Os

\footnotetext{
${ }^{13}$ Cf. Frevo, de 1961, pintura em técnica não identificada, disponível em: http:// www.portinari.org.br.
}

Motriz, Rio Claro, v.17, n.3, p.498-510, jul./set. 2011 
traços são mais visíveis que a imagem anterior, embora a subjetividade da tela esteja marcadamente presente, dando ao observador possibilidades de leitura diferenciada. Entretanto, o campo festivo está posto como marca da cultura brasileira e expressão de sua gente, de sua simbologia e de suas necessidades.

Explorar as diferentes telas no campo educacional da educação física traz desafios acerca do entendimento de tensões constitutivas do humano, como razão e sensibilidade. As telas da temática Frevo, por exemplo, conduzem a discussões sobre o sentido/significado dessa manifestação cultural à vida das pessoas, sobretudo em Pernambuco. Podem ser feitas indagações sobre o profissional que ensina 0 frevo, sobre como o frevo se coloca como campo profissional, sobre os espaços sociais em que ele está presente, sobre sua música, grupos populares, entre outros. Podem ser realizados debates, colocando as seguintes questões a respeito da dança apresentada: Vocês a conhecem? Onde é dançada? Em que espaço? Como surgiu e por quê? Qual o significado dos movimentos, das expressões para as pessoas que as praticam? É festejada em que época, em que festa? São formas possíveis de conduzir o trabalho com imagens no contexto educacional.

Em relação à musicalidade, poderemos perguntar: Como vocês podem se deslocar ao ritmo de marchinhas carnavalescas? Como trabalhar com o "outro" movimentos de capoeira? Quem pode ensinar um passo de frevo para determinado ritmo? Quem toca atabaque, flauta ou outro instrumento? Que instrumentos musicais integram o reisado, a capoeira, a marchinha?

Um dos aspectos que fascina no trato com a arte é sua capacidade de instigar as pessoas, lançando desafios, instaurando incógnitas e questionamentos, deformando aquilo que se forma (ou que se toma como certo). A subjetividade mesclada ao objetivo nos conduz a percepções distintas que revelam particularidades, auxiliando-nos a perceber 0 outro como "outro", na sua diferença e no seu valor. A arte, como elemento criador, revela-se como essencial ao processo educativo, uma vez que ensina que o conhecimento não se engessa em uma verdade, mas que várias verdades são construídas e desconstruídas pelos sujeitos históricos que somos, ensinando que a liberdade, como "bem", deve ser aprendida dia-a-dia e conquistada como direito e dever de todos.

\section{Dos carnavais de Portinari}

A representação da cultura brasileira nas telas de Portinari tem forte teor social. É a mostra daquilo que se revela à parte do que, tradicionalmente, é visto como conhecimento nessa sociedade da razão, do não movimento expressivo. Olhar para esta forma de manifestação da cultura é olhar para o diferente, para o que acaba sendo excluído justamente por revelar outros modos de ser. Se estas telas não chocam, aparentemente, como ocorre com as obras em que o artista revela seu caráter trágico, a exemplo da exploração do drama dos retirantes, seu potencial crítico e social aparece subliminarmente situado e, nem por isso, de modo menos intenso. São formas distintas de expressar a existência humana, reveladas nas várias fases de Portinari e nas formas que elege, em cada momento, para expressar sua arte.

As 11 obras selecionadas para análise, nesse estudo, contemplam vários focos que podem ser vistos de diferentes ângulos e interpretações. Trata-se da subjetividade retratada num tema aparentemente objetivo, que é o carnaval. Contudo, essa festa tem um sentido/significado especial na cultura brasileira. É a representação de um tempo-espaço peculiar em que muitas normas sociais são transgredidas para instaurar outro processo normativo. É quando canto, dança, ludicidade, êxtase, liberação da sexualidade, história, luta das comunidades populares, brincadeira e criatividade vêm à tona para configurar um cenário próprio, aceito em seu misto de rebeldia e devoção.

Em Portinari, as telas ecoam movimento e tornam possível trazer reflexões acerca do corpo, da festa, das práticas corporais, do lazer/tempo livre, da ludicidade, da cultura produzida historicamente pelos seres humanos. Traduzem, portanto, muito da educação física, dessa área do conhecimento e prática pedagógica que tematiza elementos da cultura do corpo, materializadas na forma de dança, jogos, brincadeiras, esporte, ginástica, entre outros. É nesse sentido que as imagens dão novos sentidos ao aprendizado, uma vez que instigam a sensibilidade para uma realidade posta de modo a desvendá-la, pensá-la a partir de outros contextos e significantes. Ainda, representa a possibilidade de levar os alunos à percepção de que o conhecimento possui mais de um campo visual, de uma verdade, e nem sempre se mostra de modo objetivo. A subjetividade 
integra os diferentes sujeitos e marca sua humanidade. Isso os diferencia.

As telas podem ser atrativos para pesquisa, instigando os alunos a procurarem informações sobre determinado tema (carnaval, festas, cangaceiro, capoeira, bloco carnavalesco, cavalomarinho, porta-estandarte, música), gerando outros subtemas que inspirarão novos debates. Isso pode oportunizar ricas experiências corporais que envolvam, por exemplo, expressão corporal a partir de diferentes personagens, danças diretamente reveladas nas telas ou delas decorrentes, como bumba-meu-boi, capoeira, reisado, frevo, em sua história, música e gestualidade característica, ou seja, em seu sentido ético-estético próprio (LARA, 2007).

Orientações de como tratar a dança em telas, por meio da arte de Portinari, foram desenvolvidas por Tortola (2009) e servem como inspiração ao trato com essa manifestação cultural no contexto da educação física. Os estudos de Pelegrini (2008) podem, também, inspirar reflexões diversas acerca de padrões de corpo, de formas aceitas e rejeitadas socialmente, potencializando inúmeros debates.

A prática de desenhos das telas, pelo olhar dos alunos, reproduzindo ou criando, também representa uma orientação que pode contribuir com o processo educacional, assim como ouvir músicas de frevo, capoeira, marchinha de carnaval, reisado, percebendo letra, ritmo e mensagem característica nessas manifestações, ou seja, quais sentidos a musicalidade expressa. Deslocar-se, movimentar-se, brincar consigo e com o outro por meio do estímulo musical são formas de estimular a criação. Por que nos movimentamos de determinada maneira e não de outra? O que nos faz reconhecer que se trata de um frevo e não de capoeira? Como são construídas as normas gestuais/musicais que criam modos próprios de realização?

A vivência gestual potencializada pelas imagens leva os alunos a identificar não as manifestações de forma isolada, mas relacionais, uma vez que uma manifestação folclórica tende, muitas vezes, a se mesclar a outra. Percebendo as manifestações dessa forma conseguimos visualizar melhor o processo normativo próprio que rege as diferentes danças, trazendo os alunos para uma participação conjunta.

As diferenças corporais, em forma e condição social, também são fortemente expressas nas telas de Portinari e podem ser potencializadas no trato acadêmico: que corpos vocês vêem? Há diferentes corpos? Há homens e mulheres? Há trocas de papeis sociais? Como se dá a composição de personagens durante o carnaval? Há distintas classes sociais? Como você vê os corpos diferentes? Tais questões auxiliam no debate e na formação dos sujeitos a partir da diversidade de condições existentes.

O esmiuçar possibilidades de trato com 0 conhecimento por meio da imagem nos leva, novamente, ao autor que idealizou tais expressões. Perguntar aos alunos quem foi Portinari, como se construiu a trajetória de artista, como se deu sua vida, quais as condições que teve para desenvolver sua arte, o que pintou, as relações que estabeleceu com outros profissionais, leva-os a intensificarem o interesse pela imagem, transcendendo as 11 telas iniciais rumo a outras telas e artistas. A arte, vista por alguns desses caminhos, contribui com 0 processo de formação das pessoas por vias sensíveis/racionais indispensáveis à condição de humano. Daí ressaltarmos seu caráter educativo, transformador e formador.

A educação física, justamente por não contemplar olhares uniformes e buscar interações com áreas que contribuam para ampliar seu alcance interpretativo, é espaço de interlocução com diferentes campos do saber, entre os quais a arte, possibilidade ilimitada de realização do humano. Por ela, a educação física se abre a diversas perspectivas de comunicação que se materializam por meio do corpo, da festa, da cultura popular, do tempo-espaço do lazer, da brincadeira. O carnaval coloca-se como um desses temas em que a educação física busca suas interfaces, sendo recorrente na área em estudos da cultura, do campo festivo e do lazer, a exemplo de como desenvolvem Lara (2004) e Bruhns (2000). É justamente a estrutura mosaico da educação física que permite a ela transpor barreiras no sentido de fomentar diálogos com temas variados, retornando ao seu próprio campo constitutivo com saberes reelaborados $e$ ressignificados, fugindo de qualquer colonialismo epistemológico. Assim, a educação física encontra-se aberta a diferentes diálogos que tendem a intensificar modos próprios de percebêla e legitimá-la.

\section{Considerações Finais}

A incursão pela iconografia de Cândido Portinari por meio da temática Carnaval possibilitou identificar como as imagens criam 
sentidos para o entendimento da cultura popular e de suas expressões simbólicas. Movimento, dança, festa e música estão imbricados, trazendo simbologias para pensar o sentido/significado desses tempos-espaços tão peculiares.

Portinari traz em suas obras diversas manifestações do conhecimento que se colocam como relevantes ao campo da educação física. $O$ trabalho do artista pode ser utilizado para instigar à conscientização do sujeito, levando a um entendimento de corpo para além da sua dimensão motriz e instrumental. Por meio das imagens, podemos trabalhar a expressividade, a cultura popular e as diferentes manifestações lúdicas e, ainda, questionar as formas de poder exercidas pelo corpo, pela mídia, pelo consumo e esportivização.

O estudo aponta o trabalho com imagens (iconografia) como ferramenta para investigações das manifestações da cultura popular brasileira e contribuição didática nas aulas de educação física. Isso porque Portinari traz em suas obras diversas manifestações da cultura corporal, a exemplo da dança, da luta, dos jogos, das brincadeiras, da ginástica e esporte. $\mathrm{O}$ trabalho com sua arte permite a conscientização do sujeito e se coloca como potencialidade para 0 crescimento humano. Por meio dos retratos podemos trabalhar a expressividade, a cultura popular e as diferentes manifestações lúdicas.

Algumas limitações estiveram presentes no desenvolvimento da pesquisa, relacionadas, em especial, à questão dos direitos autorais das imagens para publicação e à produção teórica existente, uma vez que contatos também foram feitos com profissionais que não disponibilizaram a produção acadêmica solicitada. Ainda, alguns empecilhos existiram no acesso à produção sobre Portinari que trata da cultura popular brasileira, uma vez que algumas temáticas são amplamente exploradas (a exemplo de Retirantes e Dom Quixote), e outras, como as manifestações da cultura brasileira na educação física, são carentes de investigação.

Trabalhando telas sobre carnaval no contexto pedagógico da educação física podemos atentar para a compreensão dessa manifestação festiva no cenário brasileiro, em sua diversidade de expressões, em sua representatividade e especificidade nas diferentes regiões, bem como em seu potencial estético, por meio de um corpo lúdico, dançante, brincante, coletivo, que traduz, na gestualidade, suas carências, suas lutas, suas diferenças e singularidades. Os carnavais de Portinari, certamente, atentam para as diferentes formas de expressão e intensificam um processo de comunicação que se traduz em modos de educar próprios. As imagens despertam racionalidades/sensibilidades que se constituem como jogo tensional no contexto da educação à medida que expressam o não dito, estimulam interpretações, aprimoram experiências e intensificam a construção de conhecimento.

\section{Referências}

BARROCO, S. S. Psicologia educacional e arte: uma leitura histórico-cultural da figura humana. Maringá: EDUEM, 2007.

BRUHNS, H. Futebol, carnaval e capoeira. Campinas, SP: Papirus, 2000.

CASCUDO, L. da C. Dicionário do folclore brasileiro. São Paulo: Global, 2000.

CASCUDO, L. da C. Antologia do folclore brasileiro. 26. ed. São Paulo: Global, 2003. v. 1.

CORTES, G. Dança, Brasil: festas e danças populares. Belo Horizonte: Leitura, 2000.

FABRIS, A. Portinari, pintor social. São Paulo: Perspectiva, 1990.

KELSEY, V. Maria Rosa. São Paulo: Record, 1983.

LARA, L. M. O sentido ético-estético do corpo na cultura popular e a estruturação do campo gestual. Movimento, Porto Alegre, v. 13, n. 03, p. 111-129, 2007.

LARA, L. M. Corpo, sentido ético-estético e cultura popular. Tese (Doutorado em Educação) - Faculdade de Educação, Universidade Estadual de Campinas, Campinas, 2004.

\section{LUZ, Â. Â. da. A fabulação trágica de Portinari} na fase dos retirantes. $1985.150 \mathrm{f}$. Dissertação (Mestrado) - Instituto de Filosofia e Ciências Sociais, Universidade Federal do Rio de Janeiro, Rio de Janeiro, 1985.

\section{PELEGRINI, T. A. Heterogeneidade antropomórfica na obra de Cândido Portinari: possibilidades de intervenção interdisciplinar na educação física. 2008. 97 f. Trabalho de Conclusão de Curso (Graduação em Educação Física) - Universidade Estadual de Maringá, Maringá, 2008.}


PORTINARI, J. C. Desfile de carnaval. [1941a]. 1 desenho, guache, nanquim; col., $25 \mathrm{~cm} \times 28,8$ $\mathrm{cm}$. Disponível em:

$<$ http://www.portinari.org.br/index.htm >. Acesso em: $07 \mathrm{fev} .2007$

PORTINARI, J. C. Maria Rosa no carro. [1941b]. 1 desenho, guache, nanquim; col., $26 \mathrm{~cm} \times 29 \mathrm{~cm}$. Disponível em:

$<$ http://www.portinari.org.br/index.htm $>$. Acesso em: 07 fev. 2007.

PORTINARI, J. C. Reisado. [1941c]. 1 desenho, guache, lápis de cor, nanquim; col., $25 \mathrm{~cm} \times 28,5$ cm. Disponível em:

$<$ http://www.portinari.org.br/index.htm >. Acesso em: 07 fev. 2007.

PORTINARI, J. C. Mascara. [1941d]. 1 pintura, óleo; col., 23,5 cm x $27 \mathrm{~cm}$. Disponível em: $<$ http://www.portinari.org.br/index.htm $>$. Acesso em: $07 \mathrm{fev} .2007$

PORTINARI, J. C. Morro. [1942a]. 1 painel a têmpera, tela; p\&b, dimensões desconhecidas. Disponível em:

$<$ http://www.portinari.org.br/index.htm >. Acesso em: 07 fev. 2007.

PORTINARI, J. C. Carnaval. [1942b]. 1 desenho, grafite, lápis de cor; p\&b, 20,5 cm x 44,5 cm.

Disponível em:

$<$ http://www.portinari.org.br/index.htm>. Acesso em: 07 fev. 2007

PORTINARI, J. C. Carnaval. 1957. 1 pintura, aquarela, grafite; col., $27,9 \mathrm{~cm} \times 48,3 \mathrm{~cm}$.

Disponível em:

$<$ http://www.portinari.org.br/index.htm>. Acesso em: 07 fev. 2007.

PORTINARI, J. C. Carnaval. [1960]. 1 pintura, óleo; col., $20 \mathrm{~cm} \times 23,5 \mathrm{~cm}$. Disponível em: $<$ http://www.portinari.org.br/index.htm>. Acesso em: 07 fev. 2007.

PORTINARI, J. C. Frevo. [1961?]. 1 pintura, técnica não identificada; p\&b., dimensões desconhecidas. Disponível em: $<$ http://www.portinari.org.br/index.htm $>$. Acesso em: 07 fev. 2007.

PORTINARI, J. C. Bloco carnavalesco. c1993. 1 desenho, crayon, papel; p\&b, $35 \mathrm{~cm} \times 73 \mathrm{~cm}$. Disponível em:

$<$ http://www.portinari.org.br/index.htm >. Acesso em: 07 fev 2007.

PORTINARI, J. C. Projeto Portinari: criação / projeção cultural. Estudos Avançados, São Paulo, v. 14, n. 38, p. 369-400, 2000.
PROJETO PORTINARI. Disponível em: $<$ http://www.projetoportinari.org.br>. Acesso em: 07 fev. 2007.

SANTOS, P. L. dos. A imagem enquanto fonte de pesquisa: a fotografia publicitária. Revista de Iniciação Científica, Maringá, v. 2, n. 2, p. 63-68, 2000.

SILVA, L. A. D. Carnaval do Recife. Recife: Fundação de Cultura Cidade do Recife, 2000.

TORTOLA, E. R. A dança em tela: contribuições da obra de Cândido Portinari para a formação e atuação do profissional de educação física. 2009. $86 \mathrm{f}$. Trabalho de Especialização (Psicologia) Universidade Estadual de Maringá, Maringá, 2009.

TSUTSUI, A. L. N.; SOUZA,T. R. S. de. Uma visão interdisciplinar do carnaval. In: XXV CONGRESSO BRASILEIRO DE CIÊNCIAS DA COMUNICAÇÃO, 25., 2002. Salvador, 2002.

Anais. Disponível em: $<$ www.academiadosamba.com.br/monografias/tsu tsui.pdf >. Acesso em: 8 maio 2008.

VALENÇA, R. Carnaval: pra tudo se acabar na quarta-feira. Rio de Janeiro: Relume-Dumará, 1996.

Apoio: Pesquisa financiada pela Pró-Reitoria de Pesquisa e Pós-Graduação da Universidade Estadual de Maringá (UEM), contemplada pelo Edital PPG/UEM -09/2007.

Endereço:

Larissa Michelle Lara

Programa de Pós-graduação Associado em

Educação Física UEM-UEL

Av. Colombo, 5790

Maringá PR Brasil

87090-200

e-mail: Imlara@uem.br

Recebido em: 17 de outubro de 2010.

Aceito em: 21 de junho de 2011.

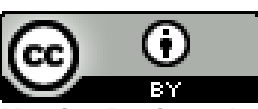

Motriz. Revista de Educação Física. UNESP, Rio Claro, SP, Brasil - elSSN: 1980-6574 - está licenciada sob Creative Commons - Atribuição 3.0 